\title{
Eating behavior and body image among psychology students
}

\author{
Comportamento alimentar e imagem corporal entre estudantes de Psicologia
}

Maria Lúcia Magalhães Bosi', Kátia Yumi Uchimura', Ronir Raggio Luiz²

\section{ABSTRACT}

Objective: To characterize eating habits and possible risk factors associated with eating disorders among psychology students, a segment at risk for eating disorders. Method: This is a cross-sectional study. The questionnaires Bulimic Investigatory Test Edinburgh (BITE), Eating Attitudes Test (EAT-26), Body Shape Questionnaire (BSQ) and a variety that considers related issues were applied. Statistical Package for the Social Sciences (SPSS) 11.0 was utilized in analysis. The study population was composed of 175 female students, with a mean age of 21.2 (DP \pm 3.6 years). Results: A positive result was detected on the EAT-26 for $6.9 \%$ of the cases (C195\%: 3.6-11.7\%). The prevalence of increased symptoms and intense gravity, according to the BITE questionnaire was 5\% (C195\%: 2.4-9.5\%) and 2.5\% (C195\%: 0.7-6.3\%), respectively. According to the findings, $26.29 \%$ of the students presented abnormal eating behavior. The population with moderate/severe BSQ scores presented dissatisfaction with

\section{Keywords}

Eating disorders, bulimia, anorexia, body image, female university students. corporal weight. Conclusion: The results indicate that attention must be given to eating behavior risks within this group. A differentiated gaze is justified with respect to these future professionals, whose practice is jeopardized in cases in which they are themselves the bearers of installed symptoms or precursory behavior.

\section{RESUMO}

Objetivo: Caracterizar práticas alimentares e possíveis fatores de risco associados a transtornos do comportamento alimentar entre estudantes de Psicologia, segmento de risco para o surgimento de transtornos alimentares. Método: Estudo seccional utilizando-se os questionários Bulimic Investigatory Test Edinburgh (BITE), Eating Attitudes Test (EAT-26) e Body Shape Questionnaire (BSQ), utilizando-se, ainda, uma variável que considera os dois primeiros instrumentos associados, sendo a análise feita através do Statistical Package for the Social Sciences (SPSS) 11.0. Foram analisadas 175 estudantes do sexo feminino, com uma média de idade de 21,2 (DP \pm 3,6 anos). Resultados: Detectou-se resultado positivo em 6,9\% (IC95\%: 3,6-11,7\%) no EAT-26. No BITE, para sintomas elevados e gravidade intensa, foram encontradas prevalências de 5\% (IC95\%: 2,4-9,5\%) e 2,5\% (IC95\%: 0,7-6,3\%), respectivamente. Constatou-se que 26,29\% das estudantes apresentavam comportamento alimentar anormal. A população com escores moderado/serevo no BSQ apresentou insatisfação com o peso corporal. Conclusão: Os resultados indicam que se deve atentar para comportamentos alimentares de risco nesse grupo, justificando-se um olhar diferenciado em relação a esses futuros profissionais, cujas práticas ficam comprometidas nos casos em que os mesmos são portadores de síndromes instaladas ou comportamentos precursores.

1 Universidade Federal do Ceará (UFC), Programa de Estudos de Graduação em Saúde Pública, Escola de Medicina da UFC. 2 Universidade Federal do Rio de Janeiro (UFRJ), Instituto de Estudos em Saúde Coletiva, Núcleo de Estudos em Saúde Coletiva (NESC). 


\section{INTRODUCTION}

Eating disorders are defined as deviances regarding eating behavior that may lead to death. In certain cases, it is estimated that the rate of lethality may reach $20 \%$. Among the eating behavior disorders, there has been an increase in the prevalence and incidence of anorexia nervosa and bulimia nervosa, particularly among adolescents and young adult women'. It is estimated that, among young women, 20\% find themselves at risk for developing these pathologies, for they present subclinical behavioral precursors².

In general, the prevalence of anorexia nervosa varies from 0.5 to $3.7 \%$ and the prevalence of bulimia nervosa varies from 1.1 to $4.2 \% \%^{1,3}$, presenting high rates not only in developed nations, where economic and sociocultural characteristics for triggering it off subsist, but also in third world countries ${ }^{4}$. Studies have demonstrated an increase in its incidence in the past decades ${ }^{5}$.

This incidence increases even further among some occupational groups (models, ballerinas, athletes and health professionals) that seem to be particularly vulnerable to eating disorders ${ }^{1,2,6}$. In these activities, an even greater pressure exists to obtain and maintain a thin body ${ }^{6}$.

Studies such as Fiates and Sales ${ }^{6}$ and Bosi et al.'s ${ }^{7}$ suggest that individuals who are already concerned about their weight (whether it is adequate or not) and body image, opt for fields of studies related to these themes - body and eating - precisely because they already have a special interest regarding this theme. The etiology of eating disorders is conceived of, at present, as multidimensional, and innumerous other factors seem to mediate the impact of culture on individual behavior, among these, psychological and biological vulnerabilities. The clinical picture usually has, as the triggering factor, some significant event, such as losses, changes or migrations, organic diseases, body image disturbances, depression, anxiety and childhood traumas such as sexual abuse. However, the way these factors will act as a cause is not yet clear ${ }^{8}$. Furthermore, due to the "secret" character of the rituals engaged in by individuals with eating behavior disorders, diagnosis becomes difficult, particularly in its initial phase, which makes prevention and early treatment more difficult?

Currently, it is acknowledged that the best results in treating eating disorders are reached through the joint efforts of multiprofessional teams and that it becomes fundamental to work in the field of prevention, identifying individuals at risk ${ }^{2}$, and above all to investigate the issue within the professional categories directly involved in it's prevention and in the clinical management of these cases. In this sense, within the sphere of this investigation, the objective was to contribute towards the assessment of the prevalence of abnormal eating behaviors among female undergraduates studying psychology.

\section{METHODS}

A cross-sectional study was conducted and with a sample of 175 female undergraduate students, attending to the psychology course of a public university located in the city of Rio de Janeiro. The sample was defined based on statistical procedures, considering $10 \%$ as the estimated prevalence of eating disorders as proposed by Nunes ${ }^{10}$, adopting the confidence interval of $95 \%$. To study the associations, the chi-square test was used. The fieldwork was developed during three months.

The evaluation of nutritional status was done based on the body mass index (BMI). The BMI was calculated based on the variables current and desired (ideal) weight and height, as reported by the students. It was not possible to confer these statements by direct anthropometric measurements. Classification was undertaken from the cut-off points established by the World Health Organization (1995).

Investigation as to eating behavior was undertaken by means of self-report questionnaires in versions translated to Portuguese ${ }^{11}$ further detailed below. Informants' adherence, once they became aware of the objectives of the study, was spontaneous. Participation was exempt from any form of remuneration, not implying in any risk of moral or physical harm. The self-applied instruments were numbered progressively, unsigned and without any other form of identification, so as to guarantee the anonymity of participants. Questionnaires were applied within the installations of the institution, within previously chosen schedules, respecting the students' availability.

In order to evaluate attitudes and typical behavior of patients with anorexia nervosa and the index of severity that characterizes eating behavior disorders, the Eating Attitudes Test (EAT-26) ${ }^{12}$ was adopted. The EAT-26 is an internationally acknowledged self-report instrument employed in the evaluation and identification of abnormal eating patterns, being useful in accompanying the evolution of clinical cases. The instrument comprises of 26 items, with six reply options: always, very frequently, frequently, sometimes, rarely and never. Factor analysis of these items is conducted, taking into consideration three aspects:

- Factor 1: Diet - the first 13 items that reflect pathological refusal towards foods with a high caloric intake and concern with physical shape;

- Factor 2: Bulimia nervosa - the following six items, that reflect thinking on food and bulimic attitudes; 
- Factor 3: Oral control - the last seven items reflect selfcontrol regarding food and acknowledge the existence of social pressures in the environment to gain weight.

Evaluation of the responses to the EAT-26 is conducted by attributing three scores to each item for which the most extreme anorexic response was marked ("always" or "never"), two scores for the second most extreme response and one score for the third most extreme response; the other replies do not receive scores. In the present study, the cut-off was 21 points, for this presents highly satisfactory sensitivity and specificity ${ }^{13,14}$. Once the instrument was applied, the scores obtained for each question in EAT-26 are added up and computed for each person evaluated. If the sum of the scores is greater than 21, the EAT-26 is considered positive and the presence of eating attitudes which represent a risk for the development of eating disorders is confirmed.

In order to evaluate the presence of bulimic behavior, and its intensity, the Bulimic Investigatory Test Edinburgh $(B I T E)^{15}$ was adopted. This is a self-report questionnaire, composed of 33 questions and two subscales, one of which is dedicated to symptoms and the other to their severity. These scales are described below, according to Cordás and Hochgraf' ${ }^{16}$. The SYMPTOMS scale offers three groups of scores:

- High (20 or more points): this is considered a high score, with the presence of compulsive eating behavior and a large possibility of filling out the diagnostic criteria for bulimia nervosa by means of the DSM-III-R2;

- Average (10 to 19 points): this suggests an unusual eating pattern and, in general, not all criteria for bulimia are present. People with results ranging from 15 to 19 may represent either a subclinical group of individuals with compulsive eating habits, bulimics in an initial stage of this disorder or bulimics who are recuperating - these should be followed up by diagnostic interviews with specialists;

- Low (below 10 points): within the limits of normality.

BITE's severity scale is contemplated in items 6, 7 and 27 of the present study's questionnaire. It measures the severity of compulsive behavior by the frequency of certain attitudes. In cases in which the score, in the symptom's scale, is higher than 10, this scale is ramified in three stages:

- High (a score $\geq 10$ points): indicates a high degree of severity, it may be signaling the presence of psychogenic vomiting or abuse of laxatives without compulsive behavior and should be followed up by a diagnostic interview with specialists;

- Moderate (between 5 and 9 points): are considered clinically significant and should be followed up by diagnostic interviews with specialists;
- Low (up to 5 points): clinical results are not significant.

To evaluate dissatisfaction with body image, the Body Shape Questionnaire (BSQ) (validated by Cooper et al. ${ }^{17}$ ), was used, being this a means to measure the level of concern with body shape, low self-esteem due to body shape and the feeling of being fat. According to Cordás and Neves ${ }^{11}$, this questionnaire distinguishes two specific aspects of body shape image: the exact evaluation of body size and the feelings related to the body (dissatisfaction or low value of body shape). The instrument consists of 34 items with six answer options: 1) never, 2) rarely, 3) sometimes, 4) frequently, 5) very frequently, 6) always. According to the selected answer, the number corresponding to the selected option is considered as the mark for the question (example: never is worth one point). The points total obtained is summed up and the final mark is applied to each evaluated student. The classification of results is made through the points total obtained and reflects the levels of concern with body image. Results lower or equal to 80 points indicate normality standards considered as the absence of body image distortion. Results between 82 and 110 points classify as light body image distortion; between 111 and 140 classify as moderate body image distortion; and above 140 points, a serious body image distortion.

The exclusion criteria were: 1) provide incomplete questionnaires; or 2) being male. Losses were due to: 1) students absent the day when the questionnaire was applied; 2) students did not sign the Consent Statement.

This study was previously approved by the Ethics Committee of the Núcleo de Estudos em Saúde Coletiva do Hospital Clementino Fraga Filho [Collective Health Study Nucleus of the Clementino Fraga Filho Hospital], and submitted itself to the norms of Resolução CNS 196/96.

The general description of the research findings shall be presented by means of simple and relative frequencies, adopting the chi-square test for analysis of the interrelation between selected variables. Data was evaluated utilizing the 11.0 version of the Statistical Package for the Social Sciences (SPSS).

\section{RESULTS}

The sample was composed of 175 female students whose age, in average, was 21.2 years ( $D P=3.6)$. The average height reported was $1.63 \mathrm{~m}(\mathrm{DP}=6.5 \mathrm{~cm})$ and the average weight informed was $55.8 \mathrm{~kg}(\mathrm{DP}=8.6)$. The average body mass index (BMI) was $20.8 \mathrm{~kg} / \mathrm{m}^{2}$ (DP=2.3), demonstrating that the majority of the students interviewed presented a BMI considered adequate according to World Health Organization's (1995) classification. 
In order to explore satisfaction with respect to weight, the respondents were asked to state their desired weight. The difference between reported and desired weight was, on the average, $2.2 \mathrm{~kg}(\mathrm{DP}=4.3)$, indicating general dissatisfaction regarding current reported weight. When BMI was calculated according to the desired weight, its average value was $20.0 \mathrm{~kg} / \mathrm{m}^{2}$, which reinforces the desire to attain a thin pattern of beauty.

According to the self-report questionnaires, the average score for EAT-26 was 9.6 (DP=7.2) points; for the BITE - symptoms, it was $7.4(\mathrm{DP}=5.5)$ points; for BITE - severity, it was 1.7 ( $\mathrm{DP}=2.4)$ points; and for the $\mathrm{BSQ}, 81.6(\mathrm{DP}=32.7)$ points (Table 1).

Table 1. Scores among psychology students

\begin{tabular}{lcccc}
\hline & \multirow{2}{*}{ BSQ } & \multirow{2}{*}{ EAT-26 } & \multicolumn{2}{c}{ BITE } \\
\cline { 4 - 5 } & & & Severity & Symptoms \\
\hline $\mathrm{N}$ & 175 & 175 & 159 & 175 \\
Average & 81.6 & 9.6 & 1.7 & 7.4 \\
Standard Deviation & 32.7 & 7.2 & 2.4 & 5.5 \\
Minimum & 34.0 & 0.0 & 0.0 & 0.0 \\
Median & 74.0 & 8.0 & 1.0 & 6.0 \\
Maximum & 168.0 & 42.0 & 11.0 & 24.0 \\
\hline
\end{tabular}

In relation to the sample, it may be observed on Table 2 that, on BITE - symptoms scale, 118 (74.2\%) students presented a score within normal limits, 33 (20.8\%) demonstrated that they had average symptoms, indicating the presence of eating behavior risks, but application of the BITE - severity scale indicated that, in the great majority of cases, the results are not clinically significant for bulimia.

Table 2. BITE among psychology students

\begin{tabular}{lccccccccc}
\hline \multirow{2}{*}{ BITE-Severity } & \multirow{2}{*}{ Total } & \multicolumn{7}{c}{ BITE-Symptoms } \\
\cline { 3 - 10 } & & & \multicolumn{2}{c}{ Normal } & \multicolumn{2}{c}{ Average } & \multicolumn{2}{c}{ High } \\
\hline & $\mathrm{N}$ & $\%$ & $\mathrm{~N}$ & $\%$ & $\mathrm{~N}$ & $\%$ & $\mathrm{~N}$ & $\%$ \\
\hline $\begin{array}{l}\text { Without } \\
\text { Severity }\end{array}$ & 146 & 91.8 & 115 & 72.3 & 27 & 17.0 & 4 & 2.5 \\
Significant & 9 & 5.7 & 2 & 1.3 & 5 & 3.1 & 2 & 1.3 \\
Intense & 4 & 2.5 & 1 & 0.6 & 1 & 0.6 & 2 & 1.3 \\
Total & 159 & 100.0 & 118 & 74.2 & 33 & 20.8 & 8 & 5.0 \\
\hline
\end{tabular}

Table 2 also indicates that, when relating BITE - severity scale to the symptoms scale, from $8(5 \%)$ students that presented elevated symptoms for bulimic behavior, 4 (2.6\%) were also classified as significantly/intensely severe according to the BITE - severity scale.
According to the BITE - severity scale, 146 (91.6\%) students were within the normal limits, 9 (5.7\%) presented significant values and 4 (2.5\%) indicated intense severity. On the EAT-26 scale, 163 (93.1\%) students presented a value of up to 20 points and $12(6.9 \%)$ attained a score of 21 points or more $(p=0,009)$ (Table 3$)$.

Table 3. Highest scores among psychology students

\begin{tabular}{lccc}
\hline & $\mathrm{N}$ & $\%$ & $\mathrm{C} 195 \%{ }^{*}$ \\
\hline BITE - Intense severity ( $\geq 10$ points) & 4 & 2.5 & $0.7 \%-6.3 \%$ \\
BITE - Elevated symptoms ( $\geq 20$ points) & 8 & 5.0 & $2.4 \%-9.5 \%$ \\
EAT-26 positive ( $\geq 21$ points) & 12 & 6.9 & $3.6 \%-11.7 \%$ \\
\hline
\end{tabular}

Note: $195 \%=$ Confidence Interval of $95 \%$

A strong - statistically significant - association may be observed on Table 4, between the presence of behavior and symptomatic practices of anorexia nervosa (EAT-26) and the presence of bulimic behavior (BITE). The presence of high scores on EAT-26 is approximately 4.8 times greater among those classified as intense severity on BITE than among those classified as without severity according to BITE (23.1\% to $4.8 \%)$; and the presence of high EAT-26 scores is 5.5 times greater among students whose BITE symptoms scores were average/high than among those students whose BITE symptoms scores classified them as normal (17.4\% to $3.1 \%)$.

Table 4. BITE and EAT-26 among psychology students

\begin{tabular}{|c|c|c|c|c|c|c|c|}
\hline \multirow{3}{*}{ BITE scores } & \multirow{2}{*}{\multicolumn{2}{|c|}{ Total }} & \multicolumn{4}{|c|}{ EAT - 26} & \multirow{3}{*}{ P-value * } \\
\hline & & & \multicolumn{2}{|c|}{ Up to 20 points } & \multicolumn{2}{|c|}{21 points or more } & \\
\hline & N & $\%$ & N & $\%$ & N & $\%$ & \\
\hline \multicolumn{8}{|l|}{ Severity } \\
\hline $\begin{array}{l}\text { Without severity } \\
\text { or not severe }\end{array}$ & 146 & 100.0 & 139 & 95.2 & 7 & 4.8 & 0.009 \\
\hline Significant/Intense & 13 & 100.0 & 10 & 76.9 & 3 & 23.1 & \\
\hline \multicolumn{8}{|l|}{ Symptoms } \\
\hline Normal & 129 & 100.0 & 125 & 96.9 & 4 & 3.1 & 0.001 \\
\hline Average/High & 46 & 100.0 & 38 & 82.6 & 8 & 17.4 & \\
\hline
\end{tabular}

Table 5 demonstrates that the body image (BSQ) is not related to age - or, indirectly, to progression in the course. On the other hand, a statistically significant association $(p=0.007)$ is observed between BSQ and BMI and, principally, with dissatisfaction regarding weight, demonstrated by the fact that the prevalence of moderate/severe BSQ attains $90.9 \%$ among those that want to loose more than $2 \mathrm{~kg}(\mathrm{p}<0.001)$. 
Table 5 . BSQ according to some characteristics of the psychology students

\begin{tabular}{|c|c|c|c|c|c|c|c|}
\hline \multirow{3}{*}{ Characteristics } & \multirow{2}{*}{\multicolumn{2}{|c|}{ Total }} & \multicolumn{4}{|c|}{ BSQ } & \multirow{3}{*}{ P-value* } \\
\hline & & & \multicolumn{2}{|c|}{ Normal/Light } & \multicolumn{2}{|c|}{$\begin{array}{l}\text { Moderate/ } \\
\text { Severe }\end{array}$} & \\
\hline & N & $\%$ & $\mathrm{~N}$ & $\%$ & $\mathrm{~N}$ & $\%$ & \\
\hline \multicolumn{8}{|l|}{ Age } \\
\hline 17 to $19 \mathrm{yrs}$ & 53 & 31.7 & 45 & 26.9 & 8 & 25.8 & 0.351 \\
\hline 20 or 21 yrs & 47 & 28.1 & 40 & 29.4 & 7 & 22.6 & \\
\hline 22 yrs or more & 67 & 40.1 & 51 & 37.5 & 16 & 51.6 & \\
\hline Total & 167 & 100.0 & 136 & 100.0 & 31 & 100.0 & \\
\hline \multicolumn{8}{|l|}{ BMI $\left(\mathrm{kg} / \mathrm{m}^{2}\right)$} \\
\hline Up to 17.99 & 10 & 6.0 & 10 & 7.4 & 0 & 0.0 & 0.007 \\
\hline 18 to 24.99 & 149 & 88.7 & 121 & 89.6 & 28 & 84.8 & \\
\hline 25 or more & 9 & 5.4 & 4 & 3.0 & 5 & 15.2 & \\
\hline Total & 168 & 100.0 & 135 & 100.0 & 33 & 100.0 & \\
\hline \multicolumn{8}{|l|}{ Dissatisfaction with weight** } \\
\hline \multicolumn{8}{|l|}{ Wants to gain weight } \\
\hline \multicolumn{8}{|l|}{ Satisfied } \\
\hline Wants to loose up & 24 & 14.2 & 24 & 17.6 & 0 & 0.0 & \multirow{5}{*}{$<0.001$} \\
\hline to $2 \mathrm{~kg}$ & 22 & 13.0 & 22 & 16.2 & 0 & 0.0 & \\
\hline Wants to loose more & 23 & 13.6 & 20 & 14.7 & 3 & 9.1 & \\
\hline than $2 \mathrm{~kg}$ & 100 & 59.2 & 70 & 51.5 & 30 & 90.9 & \\
\hline Total & 169 & 100.0 & 136 & 100.0 & 33 & 100.0 & \\
\hline
\end{tabular}

${ }^{*} x^{2}$ Testi $*{ }^{*}$ weighs less than ideal weight.

On Table 6, the statistically significant association between eating behavior (EAT-26) and body image (BSQ) may be observed. The prevalence of high scores on the EAT-26 is approximately 2 times greater among those students with moderate and severe BSQ (66.7\%) than among those with normal and light BSQ (33.3\%).

Table 6 . EAT-26 and BSQ of psychology students

\begin{tabular}{|c|c|c|c|c|c|c|c|}
\hline \multirow{3}{*}{ BSQ } & \multirow{2}{*}{\multicolumn{2}{|c|}{ Total }} & \multicolumn{4}{|c|}{ EAT-26 } & \multirow{3}{*}{ P-value* } \\
\hline & & & \multicolumn{2}{|c|}{ Up to 20 points } & \multicolumn{2}{|c|}{21 or more } & \\
\hline & $\mathrm{N}$ & $\%$ & $\mathrm{~N}$ & $\%$ & $\mathrm{~N}$ & $\%$ & \\
\hline Normal & 99 & 56.6 & 98 & 60.1 & 1 & 8.3 & \\
\hline Light & 42 & 24.0 & 39 & 23.9 & 3 & 25.0 & \\
\hline Moderate & 17 & 9.7 & 14 & 8.6 & 3 & 25.0 & 0.001 \\
\hline Severe & 17 & 9.7 & 12 & 7.4 & 5 & 41.7 & \\
\hline Total & 175 & 100.0 & 163 & 100.0 & 12 & 100.0 & \\
\hline
\end{tabular}

${ }^{*} x^{2}$ Test.

\section{DISCUSSION}

The results reveal a concerning frequency of eating behaviors considered abnormal in the study group. These practices may be associated with the development of partial syndromes of eating behavior disorders, characterized as "eating behaviors that are at risk and that are frankly abnormal" 7 .

When dissatisfaction with body image exists, the adoption of eating behaviors and of forms of reducing body weight that are inadequate - among women - is frequent.
Within the sphere of this study, the totality of the population with moderate/severe BSQ scores presented dissatisfaction with corporal weight, being that the great majority (90.9\%) presented the desire to loose more than $2 \mathrm{~kg}$, a fact that indicates a clear desire to loose weight ${ }^{18,19}$. And, even among the group of students that presented levels of concern with their body image considered normal/ light, it was found that an expressive proportion (51.5\%) would like to loose two or more kilos. Bosi et al. ${ }^{7}$ also identified the desire to loose two or more kilos among $88.7 \%$ of the college nutrition students whose BSQ was characterized as moderate/ severe, and, among those that had light BSQ, 40\% wanted to loose the same amount of weight.

These findings remit to the assumption that "the perception of body weight overlaps with the BMI, what means the way in which a person perceives him/herself is more decisive than her body mass in itself, for it may influence important changes in eating behavior" 7 .

Distortion of the body image constitutes an important symptom of eating behavior disorders, exercising influence in the individual's experience with his weight and body shape. Branco et al. ${ }^{18}$ detected, among female adolescents, a classic case of over-evaluating body weight, that is, among eutrophic adolescents, 39\% perceived themselves as being overweight, and, among these, $47 \%$ perceived themselves as being obese.

In the study population, $20.8 \%$ presented, in the BITE symptom scale, a score that was compatible with average symptoms that may represent a subclinical group of individuals with compulsive eating habits or in an initial stage of bulimia nervosa. This score therefore indicates an expressive presence of eating behavior associated with risks, for, although the majority does not indicate severity, the possibility that those cases in which the intensity and gravity are moderate evolve to highly severe behavior and the installation of eating behavior disorders cannot be discarded ${ }^{19,20}$.

Although the focus of Vitolo et al.'s study ${ }^{21}$ was on periodic compulsive eating and, therefore, another instrument was utilized for this diagnosis, their results should be mentioned for they comprehend inadequate eating behavior among female university students. In a sample of 220 students in the field of health, they identified compulsive eating - characterized by the ingestion of large volumes of food in a delimited period of time, accompanied by loss of control over what or how much is eaten - in $20.7 \%$ of the study group. And, when these findings were compounded with the results of students from other fields, resulting in a set of students from the fields of health, humanities, and exact sciences, the prevalence decreased to $18.1 \%$.

The prevalence of eating behavior disorders among women is variable and it may be substantially modified in function of professional or daily activities, $1,6,6,2,22$. 
EAT-26 was considered positive and confirmed the presence of eating attitudes that were associated with risks for the development of eating behavior disorders in $6.9 \%$ of the sample of students. This prevalence is not as high as found by Kirsten et al. ${ }^{23}-24.7 \%$ among Nutrition female students; or as found by Gonçalves et al..$^{24}$ and Bosi et al. ${ }^{25}$ among Physical Education students, but it is considered high and is compatible with the prevalence of anorexia nervosa in populations of female adolescents, according to Fairburn and Harrison ${ }^{22}$.

\section{CONCLUSION}

This study indicates that the university students investigated presented, in an expressive manner, at risk eating behavior. The desire to loose weight, in particular, is very relevant, since the analysis of the BMI reveals that the body, in its objective dimensions - the respondents are situated rigorously within the weight that is adequate for their height - does not justify this behavior. These results signal the need for a more attentive gaze, for they suggest the preponderance of values related to esthetics in detriment to those associated with health.

Nonetheless, a banalization of the practices of weight control and of strategies of body building is acknowledged among professionals and teachers whose work involves the identification of eating disorders. The findings of this study should serve as an alert regarding the issue of the presence of eating disorders among health professionals and, in particular, among psychologists.

\section{ACKNOWLEDGEMENTS}

The authors would like to acknowledge the financial support of the CNPq Edital Universal - Processo no 471617/02 and the Fundação José Bonifácio - UFRJ. They would also like to thank Daniella Esteves Duque Guimarães and Mariana Chaves Lopes for their collaboration.

\section{REFERENCES}

1. Pinzon V, Nogueira FC. Epidemiologia, curso e evolução dos transtornos alimentares. Rev Psiq Clin. 2004;31(4):158-160.

2. Walsh JME, Wheat ME, Freund K. Detection, evaluation and treatment of eating disorders. J Gen Intern Med. 2000;15:577-590
3. Magalhães VC, Mendonça GAS. Transtornos alimentares em universitárias: estudo de confiabilidade da versão brasileira de questionários autopreenchíveis. Rev Bras Epidemiol. 2005;8(3):236-45.

4. Moya T, Fleitlich-Bilyk B, Goodman R, Nogueira FC, Focchi PS, Nicoletti M, et al. The eating disorders section of the development and well-being assessment (DAWBA): development and validation. Rev Bras Psiquiatr. 2005;27(1):25-31.

5. Hay PJ. Epidemiologia dos transtornos alimentares: estado atual e desenvolvimentos futuros. Rev Bras Psiquiatr. 2002;24(Supl III):13-7.

6. Fiates GMR, Salles RK. Fatores de risco para o desenvolvimento de distúrbios alimentares: um estudo em universitárias. Rev Nutr. 2001;14 (Supl):3-6.

7. Bosi MLM, Luiz RR, Morgado CMC, Costa MLS, Carvalho RJ. Autopercepção da imagem corporal entre estudantes de nutrição: um estudo no município do Rio de Janeiro. J Bras Psiquiatr. 2006; 55(2):108-113.

8. Saikali CJ, Soubhia CS, Scalfaro BM, Cordás TA. Imagem corporal nos transtornos alimentares. Rev Psiq Clín. 2004;31(4):164-166.

9. Bosi MLM, Palha F0. Comportamentos bulímicos em atletas adolescentes corredoras de fundo. Rev Bras Psiquiatr. 2004;26(1):32-4.

10. Nunes MAA. Prevalência de comportamentos alimentares anormais e práticas inadequadas de controle de peso em mulheres de 12 a 21 anos em Porto Alegre [Dissertação de mestrado]. Porto Alegre, RS: Universidade Federal de Pelotas, 1997.

11. Cordás TA, Neves JEP. Escalas de avaliação de transtornos alimentares. Rev Psiq Clín. 1999;26:41-8.

12. Garner D, Garfinkel P. Eating attitudes test: an index of the symptoms of anorexia nervous. Psychol Med. 1979;9:273-9.

13. Mann AH, Wakeling A, Wood K, Monck E, Dobbs R, Szmuller G. Screening for abnormal eating attitudes and psychiatric morbidity in an unselected population of 15-year-old schoolgirls. Psychol Med. 1983;13:573-80.

14. Johnson-Sabine E, Wood K, Patton G, Mann A, Wakeling A. Abnormal eating attitudes in London schoolgirls. A prospective epidemiological study: factors associated with abnormal response on screening questionnaires. Psychol Med. 1988;18:615-22.

15. Hendrson M, Freeman CPL. A self-rating scale for bulimia - The BITE. Br J Psychiatry. 1987;50:18-24.

16. Cordás TA, Hochgraf PB. 0 "BITE": instrumento para avaliação da bulimia nervosa versão para o português. J Bras Psiquiatr. 1993;42:141-4.

17. Cooper P, Taylor MJ, Cooper Z, Fairburn CG. The development and validation of the Body Shape Questionnaire. Int J Eat Disord. 1987;6:485-94.

18. Branco LM, Hilário MOE, Cintra IP. Percepção e satisfação corporal em adolescentes e a relação com seu estado nutricional. Rev Psiq Clín. 2006;33(6):292-6.

19. Souto S, Ferro-Bucher JSN. Práticas indiscriminadas de dietas de emagrecimento e o desenvolvimento de transtornos alimentares. Rev Nutr. 2006;19(6):693-704

20. Oliveira FP, Bosi MLM, Vigario OS, Vieira RS. Comportamento alimentar e imagem corporal em atletas. Rev Bras Med Esporte. 2003;9(6):348-56.

21. Vitolo MR, Bortolini GA, Horta RL. Prevalência de compulsão alimentar entre universitárias de diferentes áreas de estudo. Rev Psiquiatr RS. 2006;28(1):20-6.

22. Fairburn CG, Harrison PJ. Eating disorders. The Lancet. 2003;361:407-16.

23. Kirsten VR, Fratton F, Porta NBD. Transtornos alimentares em alunas de nutrição do Rio Grande do Sul. Rev Nutr. 2009;22(2):219-27.

24. Gonçalves TD, Barbosa MP, Rosa LCL, Rodrigues AM. Comportamento anoréxico e percepção corporal em universitários. J Bras Psiquiatr. 2008;57(3):166-70.

25. Bosi MLM, Luiz RR, Uchimura KY, Oliveira FP. Comportamento alimentar e imagem corporal entre estudantes de educação física. J Bras Psiquiatr. 2008:57(1):28-33. 